\title{
Synthesis and evaluation of methacrylated poly(2-ethyl-2-oxazoline) as a mucoadhesive polymer for nasal drug delivery
}

\section{Article}

Published Version

Creative Commons: Attribution 4.0 (CC-BY)

Open Access

Shan, X., Aspinall, S., Kaldybekov, D. B., Buang, F., Williams, A. C. ORCID: https://orcid.org/0000-0003-3654-7916 and Khutoryanskiy, V. V. (2021) Synthesis and evaluation of methacrylated poly (2-ethyl-2-oxazoline) as a mucoadhesive polymer for nasal drug delivery. ACS Applied Polymer Materials, 3 (11). pp. 5882-5892. ISSN 2637-6105 doi: https://doi.org/10.1021/acsapm.1c01097 Available at https://centaur.reading.ac.uk/101189/

It is advisable to refer to the publisher's version if you intend to cite from the work. See Guidance on citing.

To link to this article DOI: http://dx.doi.org/10.1021/acsapm.1c01097

Publisher: American Chemical Society

All outputs in CentAUR are protected by Intellectual Property Rights law, including copyright law. Copyright and IPR is retained by the creators or other copyright holders. Terms and conditions for use of this material are defined in the End User Agreement. 


\section{www.reading.ac.uk/centaur}

\section{CentAUR}

Central Archive at the University of Reading

Reading's research outputs online 


\title{
Synthesis and Evaluation of Methacrylated Poly(2-ethyl-2-oxazoline) as a Mucoadhesive Polymer for Nasal Drug Delivery
}

\author{
Xiaoning Shan, Sam Aspinall, Daulet B. Kaldybekov, Fhataheya Buang, Adrian C. Williams,
} and Vitaliy V. Khutoryanskiy*

Cite This: ACS Appl. Polym. Mater. 2021, 3, 5882-5892

Read Online

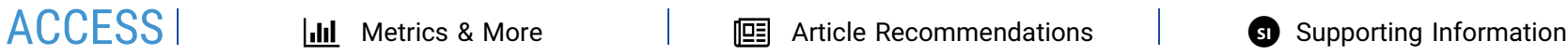

ABSTRACT: Methacrylated poly(2-ethyl-2-oxazoline) (PEOZ) was synthesized by partial hydrolysis of $500 \mathrm{kDa} \mathrm{PEOZ}$, and the resulting poly[(2-ethyl-2-oxazoline)-coethylenimine] $\mathrm{P}(\mathrm{EOZ}-\mathrm{co}-\mathrm{EI})$ was subsequently reacted with methacrylic anhydride. The successful synthesis of methacrylated PEOZ (MAPEOZ) was confirmed by proton nuclear magnetic resonance ( ${ }^{1} \mathrm{H}$ NMR), infrared spectroscopy, and differential scanning calorimetry. The degrees of hydrolysis and methacrylation were determined by ${ }^{1} \mathrm{H}$ NMR spectra. MAPEOZ exhibited temperature-responsive properties, which were dependent on the degree of methacrylation. On that basis, three soluble MAPEOZ derivatives with different degrees of methacrylation were selected and investigated in cell toxicity studies, showing no significant cytotoxicity against the HEK293 cell line. A slug mucosal irritation assay showed that PEOZ and MAPEOZ do not cause mucosal irritation. The presence of methacryloyl groups and residual amines had a remarkable synergistic effect on the mucoadhesive properties of these polymers. These poly(2-ethyl-2-oxazoline)

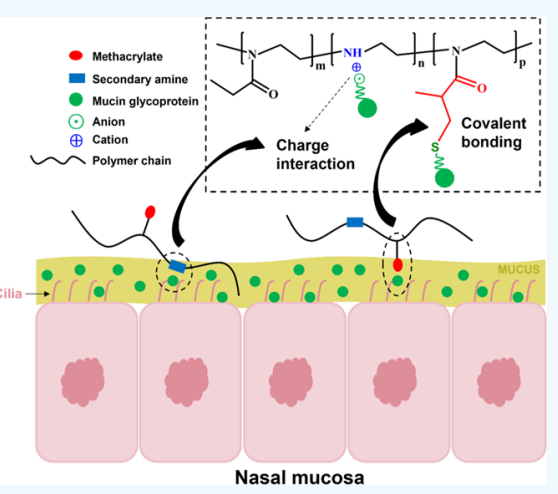
derivatives have excellent potential as mucoadhesive materials for developing formulations for drug delivery via mucosal routes of administration.

KEYWORDS: poly(2-ethyl-2-oxazoline), mucoadhesion, mucoadhesive materials, methacrylated polymers, nasal drug delivery

\section{INTRODUCTION}

Nasal administration is a readily accessible route for noninvasive treatment of rhinitis or nasal polyposis. Moreover, the human nasal mucosa surface area is around $150 \mathrm{~cm}^{2}$, and, as a tissue with a relatively high vascularization and permeability, the nose is not only a therapeutic target but also a gateway for systemic drug delivery. ${ }^{1,2}$ Consequently, dosage forms have been developed for various therapeutic purposes, including hormone replacement therapy, ${ }^{3}$ osteoporosis, ${ }^{4}$ migraine, ${ }^{5}$ and prostate cancer, ${ }^{6,7}$ and have the potential to treat different neurodegenerative disorders such as Alzheimer's, Parkinson's, and Huntington's diseases. ${ }^{8}$

However, the nasal cavity mucus layer can function as a barrier to drug diffusion to the nasal epithelium, which can result in poor drug bioavailability. To optimize nasal administration, bioadhesive or, more appropriately, mucoadhesive dosage forms such as microspheres, ${ }^{9-11}$ liposomes, ${ }^{12-14}$ and gels ${ }^{15,16}$ have been studied to prolong their residence in the nasal cavity. Polymeric dosage forms exhibiting mucoadhesive properties are usually formulated using hydrophilic polymers, which often demonstrate strong mucoadhesion. Cationic polymers such as chitosan show strong mucoadhesive properties due to interactions with mucosal surfaces. ${ }^{17-21}$ In addition, some hydrophilic polymers with methacryloyl groups, $^{22}$ acryloyl groups, ${ }^{23-26}$ and maleimide ${ }^{27-29}$ can covalently bond with the thiols present in mucus glycoproteins through a Michael-type addition; ${ }^{30}$ catechol-functionalized polymers formed covalent bonds with thiols in mucus glycoproteins via catechol oxidation. ${ }^{31}$ Further, polymeric thiomers, defined as polymers with - $\mathrm{SH}$ groups, formed covalent disulfide bridges with thiols in mucus glycoproteins. ${ }^{32-34}$ Phenylboronic acid-decorated polymers can interact with mucosal surfaces either through a covalent linkage with the sialic acid present in mucins to form reversible covalent complexes $^{35-37}$ or via hydrogen bonds with the hydroxyl groups present in oligosaccharide side chains. ${ }^{38}$

Poly(2-oxazolines) are an emerging class of polymers that are attracting significant interest due to their unique physicochemical properties and lack of toxicity. ${ }^{39-42}$ Poly(2methyl-2-oxazoline), poly(2-ethyl-2-oxazoline) (PEOZ), and poly(n-propyl-2-oxazoline) are of particular interest as drug delivery vehicles due to their solubility in water. ${ }^{43}$ However, poly(2-oxazolines) themselves tend to be poorly mucoadhesive. For example, we showed that thiolated silica nanoparticles are mucoadhesive, but POZylated (functionalized with short-

Received: August 27, 2021

Accepted: October 22, 2021

Published: November 3, 2021 
chain $5 \mathrm{kDa}$ poly(2-oxazolines)) nanoparticles became nonmucoadhesive in an ex vivo rat intestinal mucosal model ${ }^{44}$ and enhanced mucus penetration through porcine stomach mucosa. ${ }^{45}$ Larger molecular weight PEOZ $(50,200$, and 500 $\mathrm{kDa}$ ) exhibited weak mucoadhesive properties that were improved by complexation or mixing with Carbopol, ${ }^{46}$ and similarly, films formed from chitosan and PEOZ blends demonstrated mucoadhesive properties with respect to bovine cornea $^{47}$ and sheep vaginal tissue. ${ }^{48}$ These studies indicate that nonionic water-soluble poly(2-oxazolines) exhibit poor mucoadhesive properties unless mixed with more mucoadhesive materials such as chitosan or Carbopol.

To enhance the mucoadhesion of poly(2-oxazolines), here we have chemically modified the PEOZ backbone through partial hydrolysis and a subsequent reaction of the resulting poly[(2-ethyl-2-oxazoline)-co-ethylenimine $\mathrm{P}(\mathrm{EOZ}$-co-EI) with methacrylic anhydride, forming methacrylated (or methacryloylated) polymers. The products were characterized using spectroscopic ( ${ }^{1} \mathrm{H}$ nuclear magnetic resonance (NMR), Fourier transform infrared (FTIR), and UV-vis) and thermal (differential scanning calorimetry (DSC)) methods. The biocompatibility of the parent PEOZ and its hydrolyzed and methacrylated derivatives was studied in the HEK293 cell line and by using an in vivo slug mucosal irritation (SMI) assay. Aqueous solutions of PEOZ and its methacrylated derivatives containing sodium fluorescein were prepared and their retention on sheep nasal mucosa was evaluated using a fluorescence flow-through assay.

\section{EXPERIMENTAL SECTION}

2.1. Materials. Poly(2-ethyl-2-oxazoline) (PEOZ, $500 \mathrm{kDa}$, dispersity $Ð=3-4)$, methacrylic anhydride, dimethyl sulfoxide (DMSO), deuterated DMSO (DMSO- $\left.d_{6}\right)$, deuterium oxide $\left(\mathrm{D}_{2} \mathrm{O}\right)$, sodium fluorescein, glycol chitosan, benzalkonium chloride (BAC), calcium chloride dihydrate $\left(\mathrm{CaCl}_{2} \cdot 2 \mathrm{H}_{2} \mathrm{O}\right)$, sodium chloride $(\mathrm{NaCl})$, and potassium chloride $(\mathrm{KCl})$ were obtained from Sigma-Aldrich (Gillingham, U.K.). Hydrochloric acid ( $\mathrm{HCl} ; 37 \mathrm{wt} \%)$, triethylamine (TEA; 99.7\%, extra pure), and phosphate-buffered saline (PBS) tablets were obtained from Fisher Scientific (Loughborough, U.K.). Dialysis membrane with a molecular weight cutoff of $7 \mathrm{kDa}$ was purchased from Medicell Membranes Ltd. (U.K.). DMEM high glucose was purchased from Capricorn Scientific (Germany). Fetal calf serum (10\%) was purchased from GE Healthcare Life Sciences. Penicillin/streptomycin (1\%) was purchased from Nacalai Tesque Inc. (Japan). CellTiter 96 Aqueous MTS Reagent Powder was purchased from Promega Corporation. Phenazine methosulfate was purchased from Thermo Fisher Scientific.

2.2. Partial Hydrolysis of Poly(2-ethyl-2-oxazoline). PEOZ was partially hydrolyzed to poly[(2-ethyl-2-oxazoline)-co-ethylenimine], $\mathrm{P}(\mathrm{EOZ}-\mathrm{co}-\mathrm{EI})$, copolymers according to reported procedures $^{49,50}$ with minor changes. To study the hydrolysis kinetics, PEOZ $(20.0 \mathrm{~g})$ was dissolved in $200 \mathrm{~mL}$ of $18 \mathrm{wt} \%$ aqueous $\mathrm{HCl}$ and heated for $0.5,1,1.5,2,2.5$, and $3 \mathrm{~h}$ at $100{ }^{\circ} \mathrm{C}$. Subsequently, the mixture was cooled in an ice-water bath to quench the reaction. The obtained mixture was then mixed with a portion of deionized water and purified by dialysis via a cellulose-based membrane with $7 \mathrm{kDa}$ MWCO at room temperature. All copolymers were recovered by freeze-drying.

2.3. Synthesis of Methacrylated Poly(2-ethyl-2-oxazoline). Methacrylated poly(2-ethyl-2-oxazoline) (MAPEOZ) was synthesized by reacting ethylenimine groups of $\mathrm{P}(\mathrm{EOZ}-\mathrm{co}-\mathrm{EI})$ with methacrylic anhydride to generate four derivatives (with four degrees of methacrylation) according to the reported method ${ }^{22}$ with slight modifications. Briefly, P(EOZ-co-EI) (1 equiv of amines) was dissolved in a mixture of DMSO and deionized water $(1: 1 \mathrm{v} / \mathrm{v})$. Methacrylic anhydride ( 2.5 equiv) and TEA ( 2.5 equiv) were added to the reaction mixture, which was stirred at $40{ }^{\circ} \mathrm{C}$ overnight. The products were then redispersed in deionized water and purified by dialysis at room temperature. All polymers were then recovered by freeze-drying.

2.4. Characterization of Methacrylated Poly(2-ethyl-2oxazoline). 2.4.1. Proton Nuclear Magnetic Resonance $\left({ }^{1} \mathrm{H}\right.$ NMR). ${ }^{1} \mathrm{H}$ NMR spectra of polymers were recorded in $\mathrm{D}_{2} \mathrm{O}$ and DMSO- $d_{6}(15 \mathrm{mg} / \mathrm{mL})$ using a $400 \mathrm{MHz}$ Bruker spectrometer (Nanobay). All chemical shifts are given in ppm. MestReNova software was used for spectral analysis.

2.4.2. Fourier Transform Infrared (FTIR) Spectroscopy. FTIR spectra were recorded using a diamond attenuated total reflection (ATR) accessory on a Nicolet iS5 spectrometer. After a background scan, data were collected between 4000 and $400 \mathrm{~cm}^{-1}$ at a resolution of $4 \mathrm{~cm}^{-1}$ as an average of 64 scans; OMNIC software was used for spectral analysis.

2.4.3. Differential Scanning Calorimetry (DSC). Samples (3-5 $\mathrm{mg}$ ) were placed in pierced $T_{\text {zero }}$ aluminum pans. The thermal properties of each sample were investigated using a DSC (TA Instruments) in a nitrogen atmosphere with a heating/cooling rate of $10{ }^{\circ} \mathrm{C} / \mathrm{min}$ from 10 to $150{ }^{\circ} \mathrm{C}$. The values of the glass-transition temperature $\left(T_{\mathrm{g}}\right)$ were determined from the second heating cycle of each sample.

2.4.4. ${ }^{1} \mathrm{H} N M R$ to Calculate PEOZ Hydrolysis. Hydrolysis of poly(2-ethyl-2-oxazoline) to poly[(2-ethyl-2-oxazoline)-co-ethylenimine] was determined from ${ }^{1} \mathrm{H}$ NMR spectra in $\mathrm{D}_{2} \mathrm{O}$ using the signals (as shown in Figure S1) and the integrated areas (I) of the peaks assigned to either PEOZ or its hydrolysis product; conversion was calculated according to ${ }^{45}$

$$
\% \text { conversion } \mathrm{PEOZ}=\frac{I[\mathrm{EI}]}{I[\mathrm{EI}]+I[\mathrm{EOZ}]} \times 100
$$

where $I[\mathrm{EOZ}]$ is the integral value of $\mathrm{EOZ}$ moieties and $I[\mathrm{EI}]$ is the integral value of EI moieties.

2.4.5. ${ }^{1} \mathrm{H} N M R$ to Determine the Composition of MAPEOZ Samples. The degree of methacrylation was calculated from ${ }^{1} \mathrm{H}$ NMR spectra in $\mathrm{D}_{2} \mathrm{O}$ using the integrated areas (I) from the methacrylated products (Figure S3).

$$
\begin{aligned}
& \text { methacrylation } \%=\frac{I[\mathrm{MA}]}{I[\mathrm{EOZ}]+I[\mathrm{EI}]+I[\mathrm{MA}]} \times 100 \\
& \mathrm{EI} \%=\frac{I[\mathrm{EI}]}{I[\mathrm{EOZ}]+I[\mathrm{EI}]+I[\mathrm{MA}]} \times 100 \\
& \mathrm{EOZ} \%=\frac{I[\mathrm{EOZ}]}{I[\mathrm{EOZ}]+I[\mathrm{EI}]+I[\mathrm{MA}]} \times 100
\end{aligned}
$$

where $I[\mathrm{MA}]$ is the integral value of the backbone of methacrylated moieties, $I[\mathrm{EOZ}]$ is the integral value of the backbone of EOZ groups, and $I[\mathrm{EI}]$ is the integral value of EI groups.

Given that the signal of EOZ groups overlapped with the signal of MA (Figure 2), according to

$$
\frac{I[\mathrm{MA}]}{4}=\frac{I\left[\mathrm{MA} \mathrm{CH}_{3}\right]}{3} \text { and } \frac{I[\mathrm{EOZ}]}{4}=\frac{I\left[\mathrm{PEOZ} \mathrm{CH}_{3}\right]}{3}
$$

where $I\left[\mathrm{MA} \mathrm{CH} \mathrm{CH}_{3}\right]$ is the integral value of $-\mathrm{CH}_{3}$ of methacrylated moieties and $I\left[\mathrm{EOZ} \mathrm{CH} \mathrm{CH}_{3}\right]$ is the integral value of $-\mathrm{CH}_{3}$ of $\mathrm{EOZ}$ moieties, eqs 2,3 , and 4 were modified to

$$
\begin{aligned}
& \text { methacrylation } \%=\frac{4 I\left[\mathrm{MA} \mathrm{CH}_{3}\right]}{4 I\left[\mathrm{EOZ} \mathrm{CH}_{3}\right]+3 I[\mathrm{EI}]+4 I\left[\mathrm{MA} \mathrm{CH}_{3}\right]} \\
& \times 100 \\
& \mathrm{EI} \%=\frac{3 I[\mathrm{EI}]}{4 I\left[\mathrm{PEOZ} \mathrm{CH}_{3}\right]+3 I[\mathrm{EI}]+4 I\left[\mathrm{MA} \mathrm{CH}_{3}\right]} \times 100 \\
& \mathrm{EOZ} \%=\frac{4 I\left[\mathrm{EOZ} \mathrm{CH}_{3}\right]}{4 I\left[\mathrm{EOZ} \mathrm{CH}_{3}\right]+3 I[\mathrm{EI}]+4 I\left[\mathrm{MA} \mathrm{CH}_{3}\right]} \times 100
\end{aligned}
$$




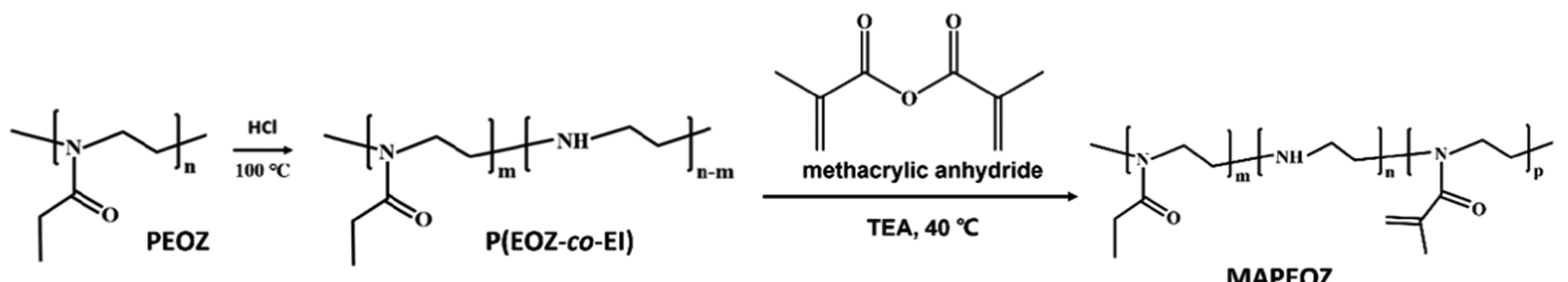

Figure 1. Synthesis of methacrylated poly(2-ethyl-2-oxazoline) (MAPEOZ).

2.4.6. Turbidity Measurements. Turbidity measurements were performed with a Cary $100 \mathrm{UV}$-vis spectrometer equipped with a Cary temperature controller (Agilent Technologies). All polymers were dissolved in deionized water $(1 \mathrm{mg} / \mathrm{mL})$ and measured at 600 $\mathrm{nm}$ with $1{ }^{\circ} \mathrm{C} / \mathrm{min}$ ramp (measurement wait time of $30 \mathrm{~s}$ and measurement interval of $1{ }^{\circ} \mathrm{C}$ ). The absorbance data were converted to transmittance by the following equation

$$
\% T=10^{-A}
$$

where $T$ is the transmittance and $A$ is the absorbance. The resulting value was then plotted as $\% T$ versus temperature.

2.5. In Vitro Nasal Mucoadhesion Studies. 2.5.1. Preparation of Polymer/Fluorescein Sodium Mixtures and Artificial Nasal Fluid. Artificial nasal fluid (ANF) was prepared using the established protocols ${ }^{25,51}$ by dissolving $7.45 \mathrm{~g}$ of $\mathrm{NaCl}, 1.29 \mathrm{~g}$ of $\mathrm{KCl}$, and $0.32 \mathrm{~g}$ of $\mathrm{CaCl}_{2} \cdot 2 \mathrm{H}_{2} \mathrm{O}$ in $1 \mathrm{~L}$ of deionized water. The artificial nasal fluid was kept at $37^{\circ} \mathrm{C}$ throughout the experiments.

Solutions of sodium fluorescein $(0.05 \mathrm{mg} / \mathrm{mL})$ were prepared in deionized water into which polymer samples were dissolved; $10 \mathrm{mg}$ of either PEOZ, $\mathrm{MA}_{10} \mathrm{PEOZ}, \mathrm{MA}_{25} \mathrm{PEOZ}, \mathrm{MA}_{35} \mathrm{PEOZ}$, or glycol chitosan was dispersed in $10 \mathrm{~mL}$ of the sodium fluorescein solution and the $\mathrm{pH}$ was adjusted to 5.70 . These mixtures were stirred for $24 \mathrm{~h}$ at room temperature until complete dissolution and were protected from light with an aluminum foil.

2.5.2. Retention Studies on Nasal Mucosa. Sheep heads were received from P.C. Turner Abattoir (Farnborough, U.K.) and used within $24 \mathrm{~h}$ after animal slaughter. The nasal septum mucosal tissue $\left(1.5 \times 1 \mathrm{~cm}^{2}\right)$ was dissected with scissors and washed with $1 \mathrm{~mL}$ of ANF.

All experiments assessing retention of formulations on nasal mucosal tissues were conducted at $37{ }^{\circ} \mathrm{C}$ in an incubator. Images of mucosal surfaces were taken using a fluorescence microscope (MZ10F, Leica Microsystems, U.K.) equipped with an "ET GFP" filter and a Zeiss Imager A1/AxioCam MRm camera. All images were at $0.8 \times$ magnification with a $211 \mathrm{~ms}$ exposure time. Initially, the fluorescence images of mucosal tissues were recorded for each sample to collect the background fluorescence intensity. Then, $20 \mu \mathrm{L}$ solution of either $1 \mathrm{mg} / \mathrm{mL}$ PEOZ, $\mathrm{MA}_{10} \mathrm{PEOZ}, \mathrm{MA}_{25} \mathrm{PEOZ}, \mathrm{MA}_{35} \mathrm{PEOZ}$, or glycol chitosan containing $0.05 \mathrm{mg} / \mathrm{mL}$ sodium fluorescein was placed on the mucosal surface and fluorescence images were recorded again. After $3 \mathrm{~min}$ of dosing, the mucosal tissues were transferred to the incubator and washed with ANF using a syringe pump at $0.43 \mathrm{~mL} /$ min. Fluorescence images of the mucosal tissue were collected periodically and analyzed using ImageJ software to measure the pixel intensity after each wash. The results are presented as fluorescence intensity as a function of the time of irrigation after subtracting the background fluorescence from each wash image. Sodium fluorescein solution in deionized water $(0.05 \mathrm{mg} / \mathrm{mL})$ was used as a negative control, and glycol chitosan solution $(1 \mathrm{mg} / \mathrm{mL})$ was used as a positive control. The experiments were conducted in triplicate.

2.6. Toxicology. 2.6.1. Cell Toxicity Studies. HEK293 was cultured in DMEM high glucose supplemented with $10 \%$ fetal calf serum and $1 \%$ penicillin/streptomycin. The cells were incubated at 37 ${ }^{\circ} \mathrm{C}$ in a humidified atmosphere of $5 \% \mathrm{CO}_{2}$. Cell viability was assessed using the CellTiter 96 AQueous Non-Radioactive Cell Proliferation Assay (MTS assay). The cells were seeded in a 96-well plate at $3 \times$ $10^{3}$ cells/well and incubated overnight for cell attachment. The cells were then treated with various concentrations of the polymers $(25,50$,
$75,100,125$, and $150 \mu \mathrm{g} / \mathrm{mL}$ ) for $72 \mathrm{~h}$. The negative control group consisted of untreated cells and was considered as $100 \%$ of viable cells. After $72 \mathrm{~h}$, treatment media were replaced with new growth media and $20 \mu \mathrm{L}$ of MTS solution (prepared in phosphate-buffered saline) containing $2 \mathrm{mg} / \mathrm{mL}$ CellTiter 96 Aqueous MTS Reagent Powder and $0.92 \mathrm{mg} / \mathrm{mL}$ phenazine methosulfate. The cells were incubated for another $4 \mathrm{~h}$ before the absorbance (Abs) was measured at $490 \mathrm{~nm}$ using an Infinite 200 PRO microplate reader (Tecan Group Ltd., Switzerland). The results are expressed as a percentage of cell viability compared to the negative control group based on the following equation

$$
\text { cell viability }(\%)=\frac{\left(\mathrm{Abs}_{\text {treatment }}-\mathrm{Abs}_{\text {blank }}\right)}{\left(\mathrm{Abs}_{\text {control }}-\mathrm{Abs}_{\text {blank }}\right)} \times 100
$$

2.6.2. Slug Mucosal Irritation Assay. The slug mucosal irritation (SMI) assay was performed according to our previous reports. ${ }^{52-54} A$. lusitanicus slugs were collected in Harris Garden (Reading, U.K.). Slugs weighing between 6 and $18 \mathrm{~g}$ were individually placed in $2 \mathrm{~L}$ glass beakers lined with a paper towel moistened with $20 \mathrm{~mL}$ of phosphate-buffered saline (PBS; pH 7.40) and left for $48 \mathrm{~h}$ prior to experiments. All beakers were covered with a pierced cling film. Each slug was individually weighed and then placed in $90 \mathrm{~mm}$ plastic Petri dishes lined with Whatman filter paper moistened with either $2 \mathrm{~mL}$ of positive/negative controls ( $1 \%$ BAC prepared in PBS and PBS solution) or $2 \mathrm{~mL}$ of each test material (PEOZ, $\mathrm{MA}_{10} \mathrm{PEOZ}$, $\mathrm{MA}_{25} \mathrm{PEOZ}$, and $\mathrm{MA}_{35} \mathrm{PEOZ}$ ) prepared in PBS. The concentration of test materials $(1 \mathrm{mg} / \mathrm{mL})$ was chosen to correlate with nasal mucosal retention studies. Slugs were kept in contact with the test samples for $60 \mathrm{~min}$ and then removed, rinsed with $10 \mathrm{~mL}$ of PBS, gently wiped, and then reweighed. Mucus production (MP) was calculated using the following equation

$$
\mathrm{MP}=\frac{\left(m_{\mathrm{b}}-m_{\mathrm{a}}\right)}{m_{\mathrm{b}}} \times 100 \%
$$

where $m_{\mathrm{b}}$ and $m_{\mathrm{a}}$ are the weights of a slug before and after the experiment, respectively. Each experiment was repeated five times with different slugs, and the results were presented as mean \pm standard deviation.

2.7. Statistical Analysis. All experiments were conducted in triplicate, and data were expressed as mean \pm standard deviation with a probability of $p<0.05$ was considered as significant. GraphPad Prism statistical analysis software (version 9.0) was used to analyze data using a one-way analysis of variance (ANOVA) and paired $t$ tests.

\section{RESULTS AND DISCUSSION}

3.1. P(EOZ-Co-EI) Synthesis and ${ }^{1} \mathrm{H}$ NMR Characterization. Complete hydrolysis of $\mathrm{PEOZ}$ to prepare pure linear PEI was reported by our group recently ${ }^{55}$ and previously by Hoogenboom et al. ${ }^{56,57}$ Here, we prepared partially hydrolyzed PEOZ with some ethylene imine units remaining available for further functionalization by reaction with methacrylic anhydride (Figure 1).

To investigate the hydrolysis kinetics of $\mathrm{PEOZ}$ at $100{ }^{\circ} \mathrm{C}$, the reaction was terminated at different times $(0.5,1,1.5,2$, 


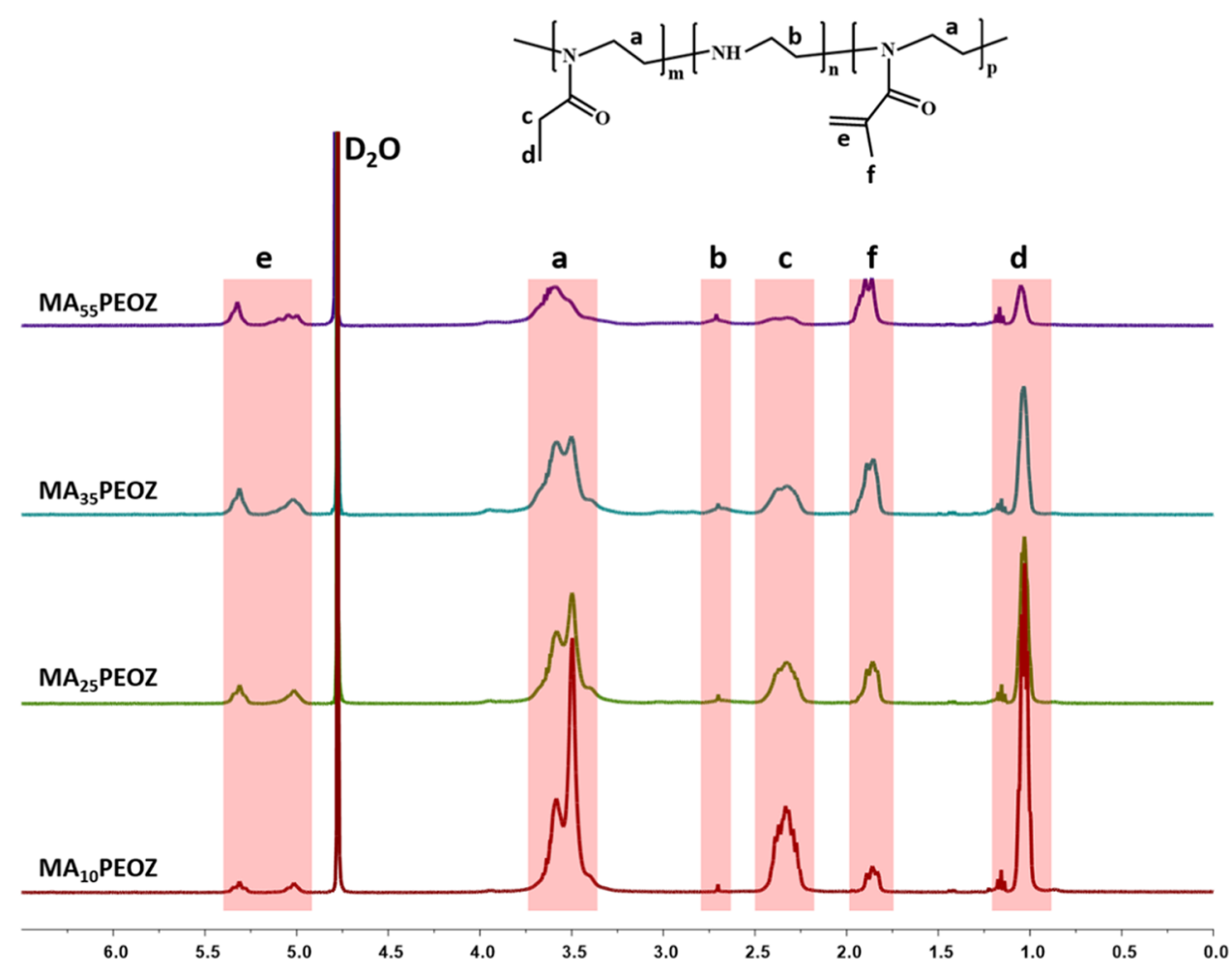

Figure 2. ${ }^{1} \mathrm{H}$ NMR spectra of MAPEOZ recorded in $\mathrm{D}_{2} \mathrm{O}$.

2.5, and $3 \mathrm{~h}$ ). The ${ }^{1} \mathrm{H}$ NMR spectra of these copolymers showed signals corresponding to the PEOZ backbone at 3.5 ppm (peak a, Figure S1) with signals 2.44 ppm (peak c) and 1.13 ppm (peak d) attributed to PEOZ side chains. Partial hydrolysis of PEOZ was confirmed not only by both reduced signals from PEOZ side chains and reduced and broadened signals from the PEOZ backbone but also by a reaction timedependent increasing signal at $3.34 \mathrm{ppm}$ (peak b, Figure S1), which was attributed to the backbone of PEI moieties. The degree of conversion from $\mathrm{PEOZ}$ to $\mathrm{P}(\mathrm{EOZ}-\mathrm{co}-\mathrm{EI})$ was calculated using eq 1 and was plotted versus time (Figure S2). Under our reaction conditions, hydrolysis of PEOZ follows first-order kinetics, which is slightly different from a previous report ${ }^{49}$ where pseudo-first-order kinetics was reported when using a microwave synthesizer with closed reactors and a lower $\mathrm{HCl}$ concentration. Taken from Figure S2, conversion from PEOZ to $\mathrm{P}(\mathrm{EOZ}-\mathrm{co}$-EI) at $0.5,1,2$, and $3 \mathrm{~h}$ was $15,28,53$, and $78 \%$ of EI, respectively (Table S1).

3.2. Synthesis and Characterization of Methacrylated PEOZ. The secondary amines present in $\mathrm{P}$ (EOZ-co-EI) offer reactive sites for further methacrylation by reaction with methacrylic anhydride in the presence of TEA as a basic catalyst. P(EOZ-co-EI) copolymers prepared following $0.5,1$, 2 , and $3 \mathrm{~h}$ of partial hydrolysis were selected for further methacrylation. The resultant MAPEOZ polymers were characterized using ${ }^{1} \mathrm{H}$ NMR, FTIR, and DSC.

The ${ }^{1} \mathrm{H}$ NMR spectra of MAPEOZ polymers showed signals corresponding to the backbone of EOZ repeating units as well as the backbone of methacrylated units at $3.5 \mathrm{ppm}$ (peak a, Figure 2); the signals labeled as $\mathrm{c}(2.44 \mathrm{ppm})$ and $\mathrm{d}$ (1.13 $\mathrm{ppm})$ are attributed to the methylene and methyl groups of EOZ units, respectively. The signal characteristic for the backbone of unreacted EI units shifted from 3.10 ppm (peak b, Figure S1) to $2.71 \mathrm{ppm}$ (peak b, Figure 2) upon modification.
The signals labeled e (5.0-5.5 ppm) and $\mathrm{f}(1.86 \mathrm{ppm})$ are attributed to the protons of the double bond and methyl of the methacryloyl group, respectively. Increasing methacrylation or decreasing EOZ units, in other words, led to a significant weakening of peaks $c$ and $d$ and strengthening of peaks e and $f$. It should be noted that the ${ }^{1} \mathrm{H}$ NMR spectrum of $\mathrm{MA}_{55} \mathrm{PEOZ}$ was recorded both in DMSO- $d_{6}$ and in $\mathrm{D}_{2} \mathrm{O}$ since this sample exhibited limited solubility in $\mathrm{D}_{2} \mathrm{O}$ (discussed below). The chemical shifts of protons of $\mathrm{MA}_{55} \mathrm{PEOZ}$ in DMSO- $d_{6}$ were consistent with the spectra of other samples recorded in $\mathrm{D}_{2} \mathrm{O}$, with some expected minor shifts related to the switch of solvent (Figure S3).

The compositions of MAPEOZ polymers were calculated using eqs 5-7 and are presented in Table 1. As expected,

Table 1. Composition of MAPEOZ Calculated from the ${ }^{1} \mathbf{H}$ NMR Spectra

\begin{tabular}{llccc}
\multicolumn{1}{c}{ sources } & \multicolumn{1}{c}{ products } & $\begin{array}{c}\mathrm{EOZ} \\
(\%)\end{array}$ & $\begin{array}{c}\mathrm{EI} \\
(\%)\end{array}$ & $\begin{array}{c}\mathrm{MA} \\
(\%)\end{array}$ \\
$\mathrm{P}\left(\mathrm{EOZ}-\mathrm{c}-\mathrm{EI}_{15}\right)$ & $\mathrm{MA}_{10} \mathrm{PEOZ}$ & 89 & 1 & 10 \\
$\mathrm{P}\left(\mathrm{EOZ}-c o-\mathrm{EI}_{28}\right)$ & $\mathrm{MA}_{25} \mathrm{PEOZ}$ & 70 & 5 & 25 \\
$\mathrm{P}\left(\mathrm{EOZ}-c o-\mathrm{EI}_{53}\right)$ & $\mathrm{MA}_{35} \mathrm{PEOZ}$ & 52 & 13 & 35 \\
$\mathrm{P}\left(\mathrm{EOZ}-c o-\mathrm{EI}_{78}\right)$ & $\mathrm{MA}_{55} \mathrm{PEOZ}\left(\mathrm{D}_{2} \mathrm{O}\right)$ & 27 & 18 & 55 \\
& $\mathrm{MA}_{55} \mathrm{PEOZ}\left(\mathrm{DMSO}-d_{6}\right)$ & 26 & 19 & 55 \\
\hline
\end{tabular}

methacrylation increased with PEOZ hydrolysis, and for clarity, the methacrylated polymers are annotated with their MA content (i.e., $\mathrm{MA}_{10}$ PEOZ contains $10 \% \mathrm{MA}$ groups and was synthesized from the PEOZ sample that had hydrolyzed for $0.5 \mathrm{~h}$ ). It can be seen that the secondary amines were not completely substituted by methacryloyl groups due to steric hindrance with $1,5,13$, and $18 \%$ residual EI units remaining in the four MAPEOZ products. The proportion of EOZ units $(89,70,52$, and $27 \%$, Table 1$)$ in the four MAPEOZ samples 
shows good agreement with the PEOZ to $\mathrm{P}(\mathrm{EOZ}-\mathrm{co}-\mathrm{EI})$ hydrolysis study $(85,72,47$, and $22 \%$, Table S1). The composition of $\mathrm{MA}_{55} \mathrm{PEOZ}$ calculated from ${ }^{1} \mathrm{H}$ NMR spectra recorded in $\mathrm{D}_{2} \mathrm{O}$ (27\% EOZ, $18 \% \mathrm{EI}$, and $\left.55 \% \mathrm{MA}\right)$ was in good agreement with the composition determined in DMSO$d_{6}(26 \% \mathrm{EOZ}, 19 \% \mathrm{EI}$, and $55 \% \mathrm{MA})$.

Infrared analysis of PEOZ provided peaks at 2977 and 2940 $\mathrm{cm}^{-1}\left(\mathrm{CH}_{2}\right.$ stretch) (Figure $\left.\mathrm{S} 4\right), 1626 \mathrm{~cm}^{-1}$ ( $\mathrm{C}=\mathrm{O}$ stretch), $1470 \mathrm{~cm}^{-1}$ ( $\mathrm{C}-\mathrm{H}$ bending), $1420 \mathrm{~cm}^{-1}$ ( $\mathrm{C}-\mathrm{H}$ bending), and $1240 \mathrm{~cm}^{-1}$ (C-N stretch). New peaks at 1719 and $916 \mathrm{~cm}^{-1}$ (Figure 3), assigned to the stretching mode and bending

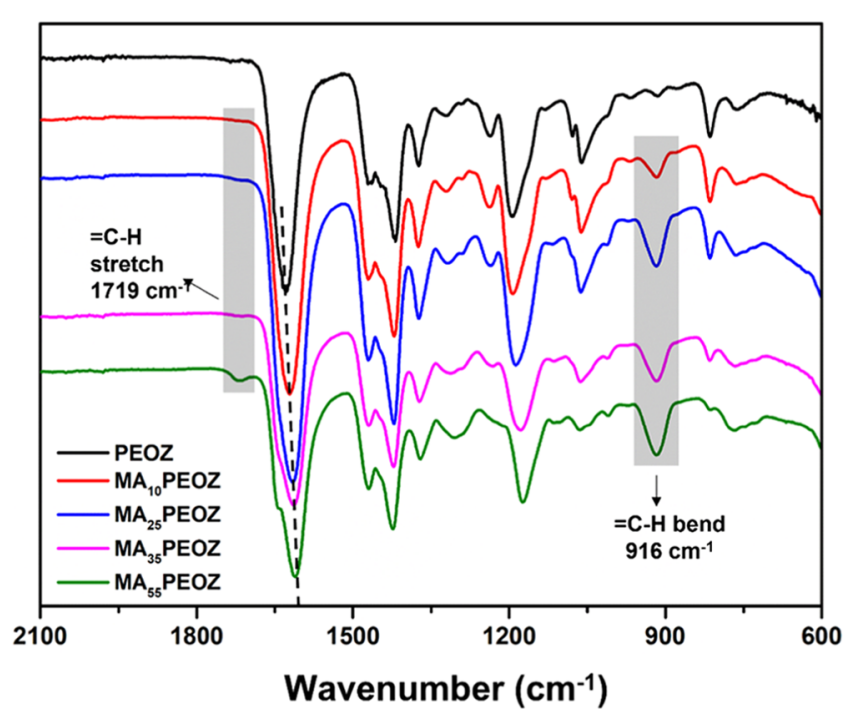

Figure 3. FTIR spectra of PEOZ and MAPEOZ in the range of $2100-600 \mathrm{~cm}^{-1}$.

modes of $=\mathrm{C}-\mathrm{H}$, became evident with increasing methacrylation, which further confirmed its successful modification. In addition, it is notable that the peak attributed to the carbonyl group of MAPEOZ gradually shifted to lower wavenumbers (1622 $\mathrm{cm}^{-1}$ for $\mathrm{MA}_{10} \mathrm{PEOZ}, 1617 \mathrm{~cm}^{-1}$ for $\mathrm{MA}_{25} \mathrm{PEOZ}, 1614 \mathrm{~cm}^{-1}$ for $\mathrm{MA}_{35} \mathrm{PEOZ}$, and $1611 \mathrm{~cm}^{-1}$ for $\mathrm{MA}_{55} \mathrm{PEOZ}$ ) with increasing methacrylation. It is problematic to detect EI moieties in these FTIR spectra because the characteristic $\mathrm{N}-\mathrm{H}$ bending mode of EI at $1474 \mathrm{~cm}^{-15555}$ overlaps with the $\mathrm{C}-\mathrm{H}$ bending mode of EOZ moieties at $1470 \mathrm{~cm}^{-1}$

PEOZ and MAPEOZ samples were also analyzed using differential scanning calorimetry (Figure 4). PEOZ, $\mathrm{MA}_{10} \mathrm{PEOZ}, \mathrm{MA}_{25} \mathrm{PEOZ}, \mathrm{MA}_{35} \mathrm{PEOZ}$, and $\mathrm{MA}_{55} \mathrm{PEOZ}$ showed glass-transition temperatures $\left(T_{\mathrm{g}}\right)$ at $60.7,62.5,64.4$, 65.2 , and $68.7{ }^{\circ} \mathrm{C}$, respectively. The increase in $T_{\mathrm{g}}$ with an increasing degree of methacrylation in MAPEOZ can be explained by the lower flexibility of the macromolecules with bulky groups, which decreases the overall chain mobility.

The thermal properties of the new polymers were also studied in aqueous solutions. To this end, PEOZ and MAPEOZ samples $(1 \mathrm{mg} / \mathrm{mL})$ were dissolved in deionized water, and their phase behavior was studied by measuring solution turbidity between 5 and $95{ }^{\circ} \mathrm{C}$ (Figure 5a). The literature describes various methods to determine the cloud point $\left(T_{\mathrm{cp}}\right)$, including the onset of the fall in transmittance, or the temperature where transmittance is 80 or $50 \%$, or by taking the inflection point of the turbidity curve. ${ }^{58}$ Here, the onset of the fall in transmittance was used as this value was accessible

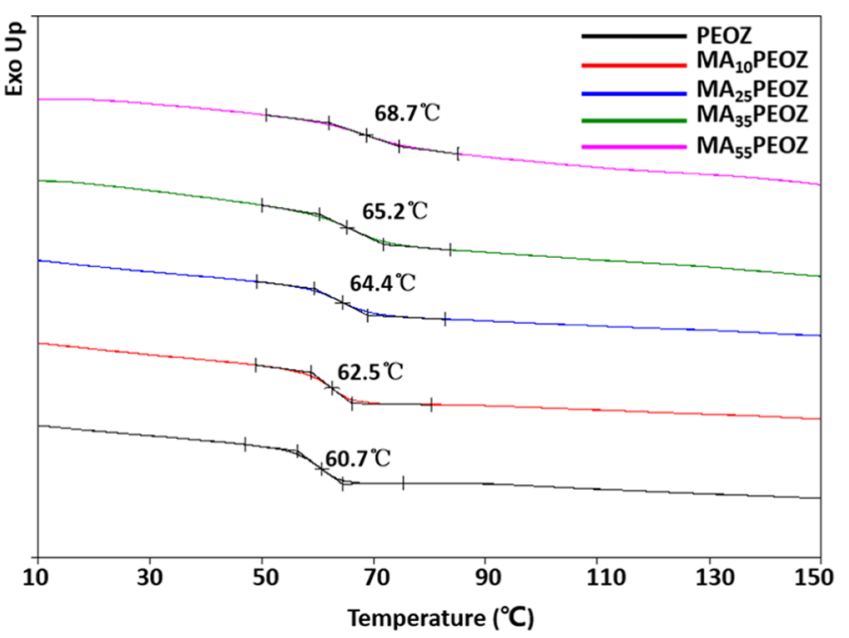

Figure 4. DSC thermograms (second scan) of PEOZ and MAPEOZ samples showing increasing glass-transition temperatures with increasing methacrylation.

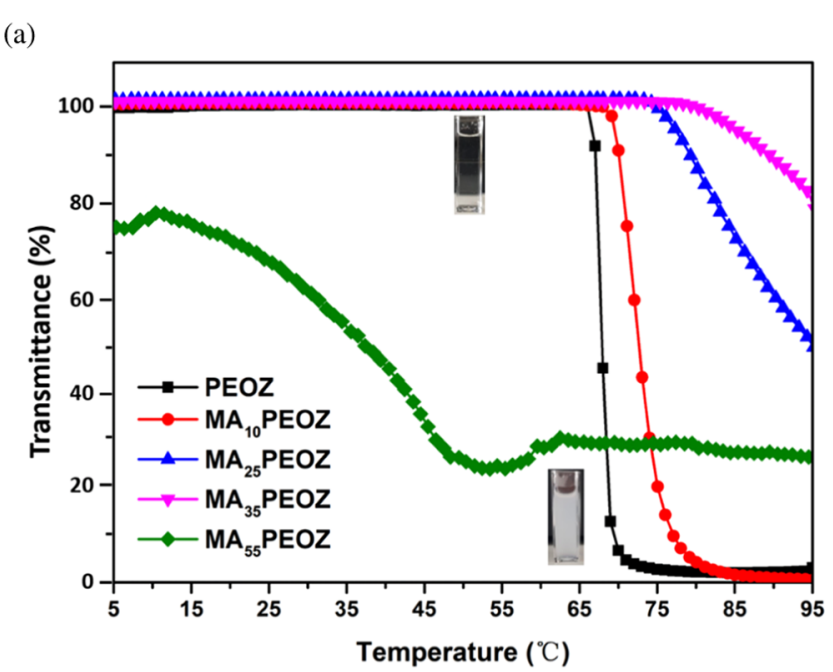

(b)

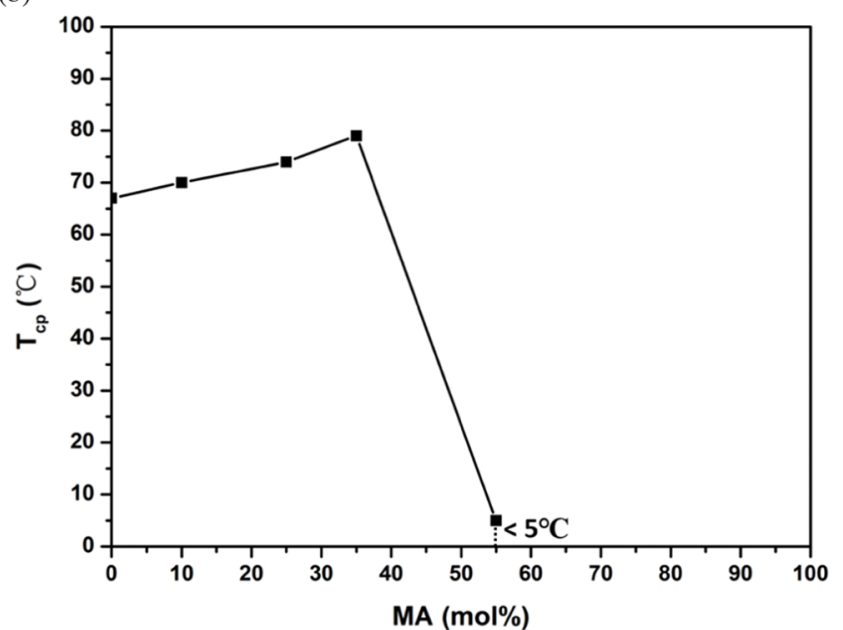

Figure 5. (a) Turbidity measurements of aqueous solutions of PEOZ and MAPEOZ samples $(1 \mathrm{mg} / \mathrm{mL})$. (b) $T_{\mathrm{cp}}$ as a function of MA mol $\%$ in MAPEOZ polymers.

for all MAPEOZ samples. PEOZ exhibited a cloud point of 67

${ }^{\circ} \mathrm{C}$, in agreement with the literature where $\mathrm{PEOZ}$ undergoes 
(a) Glycol chitosan
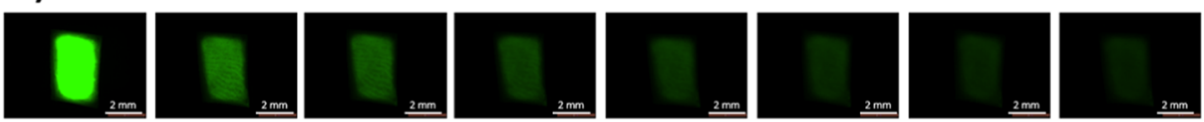

$\mathrm{MA}_{35}$ PEOZ
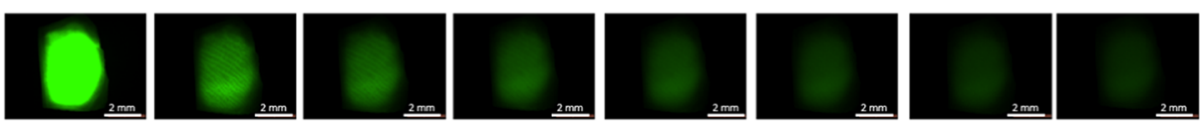

$\mathrm{MA}_{25}$ PEOZ
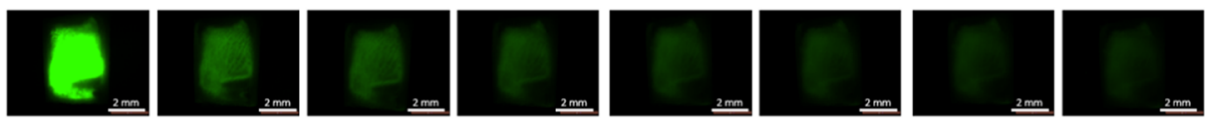

$\mathrm{MA}_{10}$ PEOZ
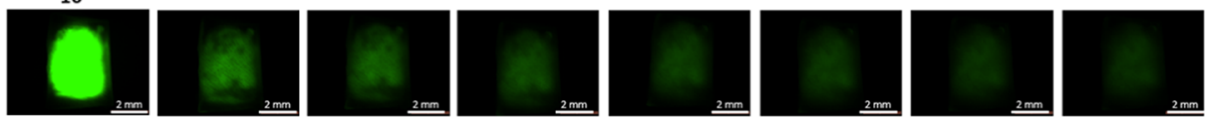

PEOZ
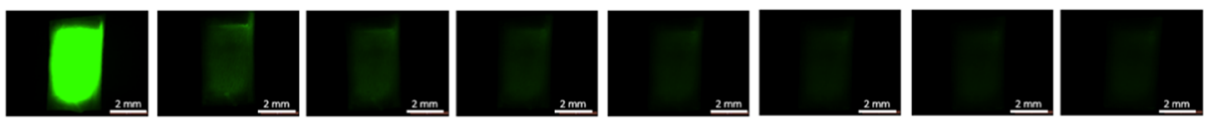

Sodium fluorescein
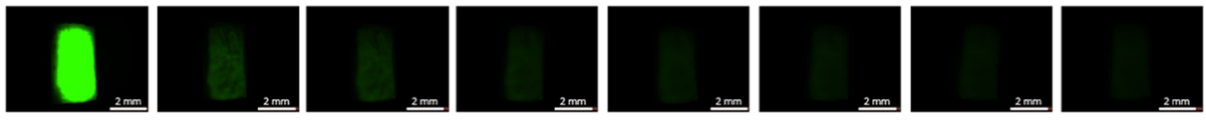

0

5

20

30

40

50

60

Time (min.)

(b)

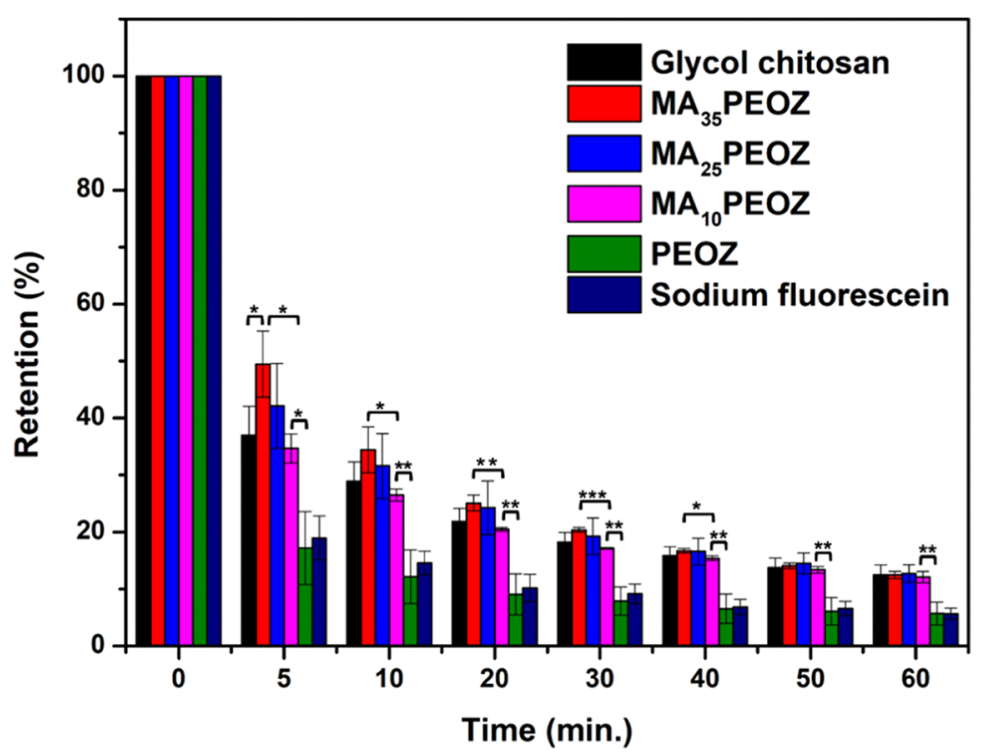

Figure 6. (a) Fluorescence images showing retention of $1 \mathrm{mg} / \mathrm{mL}$ glycol chitosan, $\mathrm{PEOZ,} \mathrm{MA}_{10} \mathrm{PEOZ}, \mathrm{MA}_{25} \mathrm{PEOZ}$, and $\mathrm{MA}{ }_{35} \mathrm{PEOZ}$ solutions using $0.05 \mathrm{mg} / \mathrm{mL}$ sodium fluorescein as the solvent and pure $0.05 \mathrm{mg} / \mathrm{mL}$ sodium fluorescein solution on sheep nasal mucosa and washed with

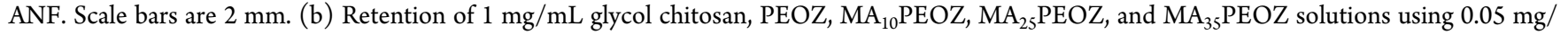
$\mathrm{mL}$ sodium fluorescein as the solvent and pure $0.05 \mathrm{mg} / \mathrm{mL}$ sodium fluorescein solution on sheep nasal mucosa as washed with different volumes of $\operatorname{ANF}(\mathrm{pH}=5.70 ; n=3$, mean $\pm \mathrm{SD}$, “*” represents $p<0.05$; “**” represents $p<0.01$; “***” represents $p<0.001)$.

phase separation between 61 and $70{ }^{\circ} \mathrm{C}$, depending on the molecular weight and the solution concentration. ${ }^{59,60}$

Methacrylate groups of MAPEOZ make the macromolecules more hydrophobic. ${ }^{61}$ Therefore, increasing the proportion of MA was expected to lower $T_{\mathrm{cp}}$. However, the results showed the opposite trend with $T_{\mathrm{cp}}$ increasing with increasing methacrylation; $T_{c p}$ values for $\mathrm{MA}_{10} \mathrm{PEOZ}, \mathrm{MA}_{25} \mathrm{PEOZ}$, and $\mathrm{MA}_{35} \mathrm{PEOZ}$ were 70,74 , and $79{ }^{\circ} \mathrm{C}$, respectively (Figure 5). The unexpected increase in $T_{\mathrm{cp}}$ may be explained by the increasing proportion of hydrophilic EI units that accompanies the increase in methacrylation (Table 1), and indeed, these may be positively charged upon protonation ${ }^{62}$ such that the 


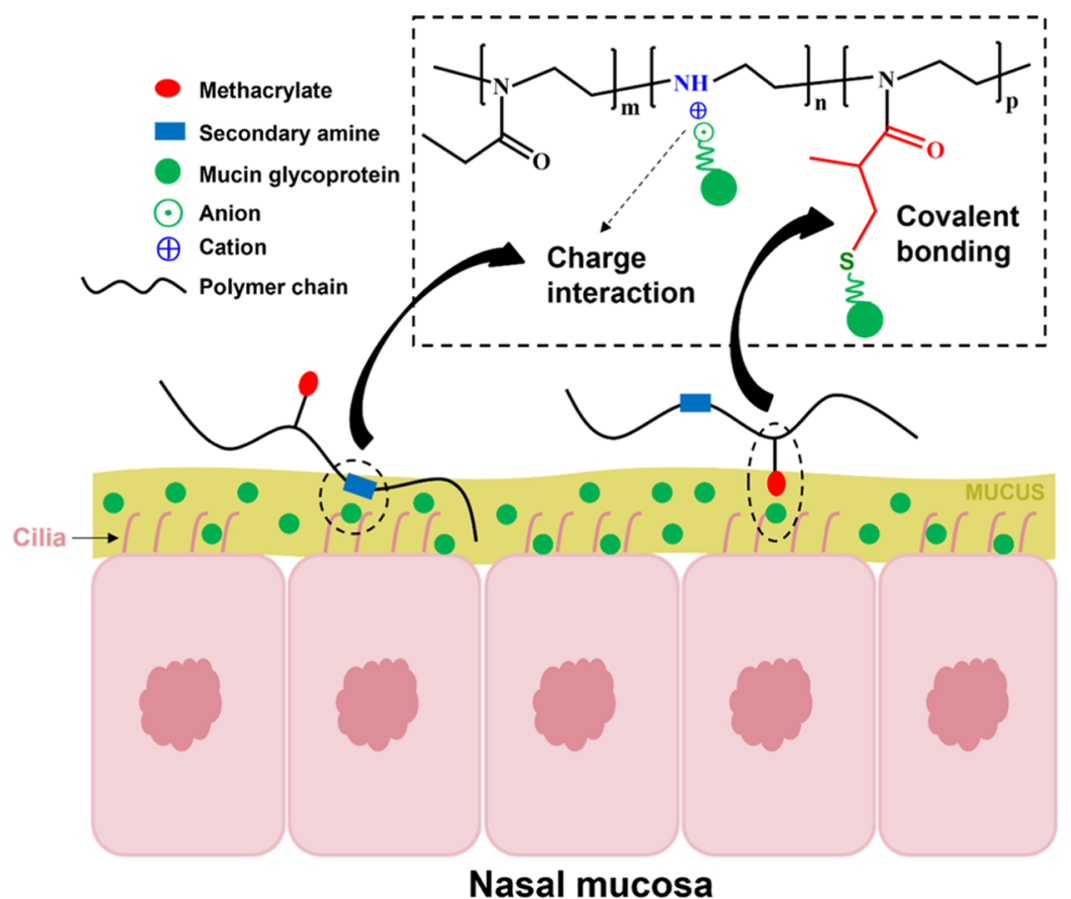

Figure 7. Proposed mechanism of interaction between MAPEOZ polymers and mucosal surfaces.

hydrophilicity of the whole macromolecule was improved. Interestingly, increasing the MA from 35 to $55 \%$ decreased the $T_{c p}$ to a temperature below $5{ }^{\circ} \mathrm{C}$ (Figure $5 \mathrm{~b}$ ); the aqueous solution of $\mathrm{MA}_{55} \mathrm{PEOZ}$ was already cloudy at $5{ }^{\circ} \mathrm{C}$. It is feasible that the high hydrophobic MA content in $\mathrm{MA}_{55} \mathrm{PEOZ}$ (MA\% 55\%) dominates the hydrophilic contribution of the EI groups and makes the macromolecules more hydrophobic than the parent PEOZ. The variability of $T_{\mathrm{cp}}$ with both MA and EI content suggests that systems can be tuned to provide a cloud point for desired applications.

3.3. In Vitro Nasal Mucoadhesion Studies. Given the limited water solubility of $\mathrm{MA}_{55} \mathrm{PEOZ}$ at $37^{\circ} \mathrm{C}$, this polymer was not used in subsequent studies.

The retention of $\mathrm{PEOZ}, \mathrm{MA}_{10} \mathrm{PEOZ}, \mathrm{MA}_{25} \mathrm{PEOZ}$, and $\mathrm{MA}_{35} \mathrm{PEOZ}$ solutions with sodium fluorescein was evaluated on sheep nasal mucosa and washed with ANF. Glycol chitosan was used as a positive control with strong mucoadhesive properties, ${ }^{19}$ whereas sodium fluorescein was used as a negative control. Figure 6 shows the retention of sodium fluorescein mediated with glycol chitosan, PEOZ, $\mathrm{MA}_{10} \mathrm{PEOZ}$, $\mathrm{MA}_{25} \mathrm{PEOZ}$, and $\mathrm{MA}_{35} \mathrm{PEOZ}$ on sheep nasal mucosa. Numerical values from these experiments are summarized in Table S2.

As expected, the water-soluble dye sodium fluorescein was poorly retained when dosed from a simple aqueous solution and was rapidly washed from the nasal mucosa surface with only $\sim 5.7 \%$ of the initial fluorescence detected after $60 \mathrm{~min}$ of washing (Figure 6b). This residual fluorescence results from the penetration of sodium fluorescein into the biological tissue rather than its adhesion to the surface. Retention of sodium fluorescein was not improved in the presence of unmodified PEOZ, confirming the poor mucoadhesive properties of PEOZ shown in our previous studies ${ }^{44}$ and attributed to the nonionic nature of this polymer. ${ }^{30}$ PEOZ samples chemically modified through hydrolysis and subsequent methacrylation significantly improved sodium fluorescein retention on the mucosal surface. Particularly notable at shorter irrigation times (5, $10 \mathrm{~min})$, increasing methacrylation led to a greater retention of the fluorescent dye. For example, after 5 min of washing, 50\% of the dye was retained when administered with $\mathrm{MA}_{35} \mathrm{PEOZ}$ compared with $42 \%$ retention when using $\mathrm{MA}_{25} \mathrm{PEOZ}$ and $35 \%$ of the dye was retained when deposited with $\mathrm{MA}_{10} \mathrm{PEOZ}$. Indeed, after $5 \mathrm{~min}$ of irrigation, $\mathrm{MA}_{35} \mathrm{PEOZ}$ retained significantly more sodium fluorescein than the positive control (cationic glycol chitosan) $(p<0.05)$.

As expected, retention declines with irrigation time, but the trend remains that mucoadhesion/mucoretention of the polymers is in the order $\mathrm{MA}_{35} \mathrm{PEOZ}>$ glycol chitosan > $\mathrm{MA}_{25} \mathrm{PEOZ}>\mathrm{MA}_{10} \mathrm{PEOZ}>\mathrm{PEOZ}$. It can be hypothesized that MAPEOZ polymers interact with mucosal surfaces through two mechanisms as shown in Figure 7: (1) the methacrylate groups could potentially form covalent bonds with the thiol groups present in mucins at the mucosal surface; (2) electrostatic interaction between cationic secondary amines within the polymer and negatively charged mucins due to the presence of carboxylate groups and ester sulfates in their structure. ${ }^{32}$ It is likely that the strong mucoadhesive properties of the MAPEOZ result from the synergistic positive effects from both the MA groups and residual secondary amines being available to interact with the mucosal surface.

3.4. Cell Toxicity Studies. The HEK 293 cell line, consisting of immortalized human embryonic kidney cells, has been used for in vitro toxicity testing with varied toxicological endpoints. ${ }^{63}$ The effects of the polymers on HEK293 cell viability were studied over $72 \mathrm{~h}$ using the MTS assay (Figure 8); numerical values as mean \pm standard deviation are summarized in Table S3. Poly(2-oxazolines) have demonstrated excellent biocompatibility in a number of studies and are proposed as a versatile platform for biomedical applications, ${ }^{39,64}$ but here, PEOZ was found to moderately affect HEK293 cells, notably at $>100 \mu \mathrm{g} / \mathrm{mL}$ where cell viability fell to below $90 \%$, consistent with a previous study. ${ }^{65}$ Hydrolyzed PEOZ with $15 \mathrm{~mol} \%$ EI units $\left(\mathrm{P}\left(\mathrm{EOZ}^{-c o-\mathrm{EI}_{15}}\right)\right.$ ) showed a similar cell viability trend to $\mathrm{PEOZ}$, suggesting that 


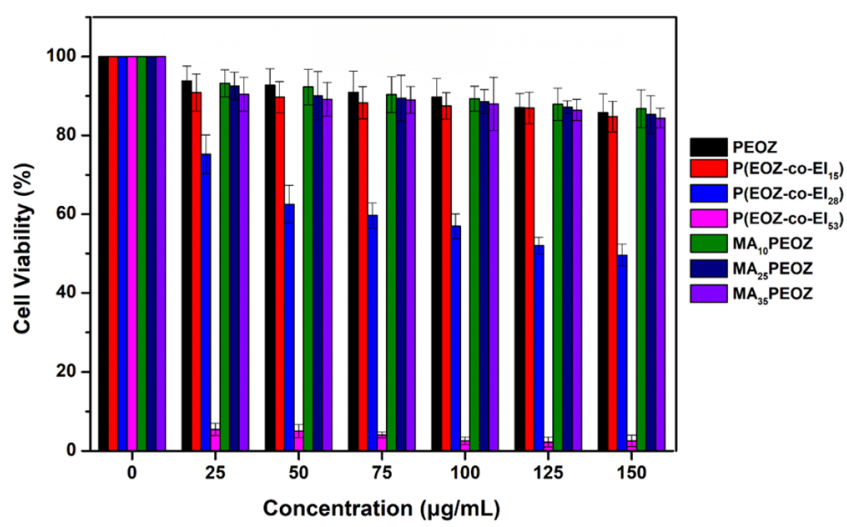

Figure 8. Viability of HEK293 cells determined after treatment with PEOZ, $\mathrm{P}\left(\mathrm{EOZ}-c o-\mathrm{EI}_{15}\right), \mathrm{P}\left(\mathrm{EOZ}-c o-\mathrm{EI}_{28}\right), \mathrm{P}\left(\mathrm{EOZ}-c o-\mathrm{EI}_{53}\right)$, $\mathrm{MA}_{10} \mathrm{PEOZ}, \mathrm{MA}_{25} \mathrm{PEOZ}$, and $\mathrm{MA}_{35} \mathrm{PEOZ}$ for $72 \mathrm{~h}$. The untreated cells served as the control. Values are expressed as means $\pm \mathrm{SD}(n=$ $3)$.

$15 \%$ EI did not alter the biocompatibility of the copolymer. However, poly(ethylenimine) (PEI), a widely used transfection agent, is known to be toxic, and so it is unsurprising that as the EI content in our hydrolyzed PEOZ increases, the cell viability declines. For example, when applied at $100 \mu \mathrm{g} / \mathrm{mL}, \mathrm{P}($ EOZ-co$\mathrm{EI}_{15}$ ) with $15 \mathrm{~mol} \% \mathrm{EI}$ units retained $>87 \%$ cell viability, but this fell to $57 \%$ when treated with the polymer containing 28 mol \% EI units and less than $3 \%$ of cells remained viable when treated with the polymer containing $53 \mathrm{~mol} \%$ EI units at the same concentration. It is known that the positive charges of EI can induce cell death and apoptosis and cause toxicity both in vitro and in vivo. ${ }^{66}$

Although the MAPEOZ polymers formed from the P(EOZco-EI) retain some EI units (Table 1), methacrylation essentially reverses or "blocks" the toxicity of the intermediate polymer and cell viability returns to the same levels seen with the parent $\mathrm{PEOZ}$ with $>90 \%$ cell viability for $\mathrm{PEOZ}$ and all MAPEOZ samples when dosed at $25 \mu \mathrm{g} / \mathrm{mL}$ and $88-90 \%$ viability for all when dosed at $100 \mu \mathrm{g} / \mathrm{mL}$. The introduction of MA groups clearly reduced the cellular toxicity of hydrolyzed PEOZ, suggesting the equivalent biocompatibility of our modified MAPEOZ with the parent poly(2-ethyl-2-oxazoline).

3.5. Mucosal Irritancy. The slug mucosal irritation (SMI) in vivo assay, developed by Adriaens and co-workers, ${ }^{67,68}$ was used to evaluate the toxicological properties of PEOZ and its methacrylated derivatives. This test has been validated as a reliable method and is useful as a prescreen assay for evaluating the irritation potential of chemicals, formulations, and active ingredients to different mucosal membranes, including evaluation of nasal irritation. ${ }^{69-73}$ The slug's mucosal layer is located at the outer surface of the body and, for this reason, it is easily observable by the investigator. In this test, colorless mucus, secreted by slugs after contact with a test substance, is a good initial indicator of biocompatibility. The total amount of mucus production serves as the main criterion to test the biocompatibility of formulations since this increases on exposure to stronger irritants..$^{54,67,74}$ These assessments provide quantifiable data for test materials to be classified as nonirritating, mild, moderate, or severely irritating. ${ }^{72,73}$

Figure 9 shows the data on mucus production by slugs exposed to filter paper surfaces soaked in PEOZ and its modified derivatives solutions at $1 \mathrm{mg} / \mathrm{mL}$ prepared in PBS, as well as positive and negative controls. On exposure to $1 \% \mathrm{BAC}$

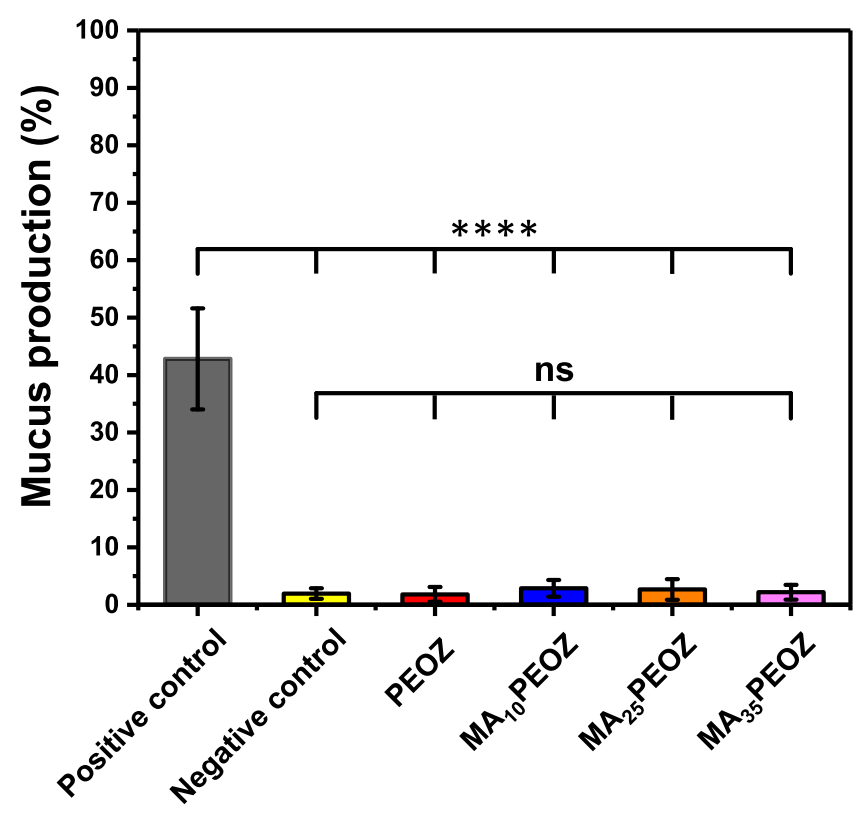

Figure 9. Mucus production by Arion lusitanicus slugs in response to 60 min exposure to PEOZ and its methacrylated derivatives as well as positive (BAC) and negative (PBS) controls. Statistically significant differences are given as follows: $* * * * p<0.0001$; ns: no significance.

in PBS (positive control; $\mathrm{pH} 7.37$ ), slugs experienced severe irritation ( $p<0.0001)$, producing $\sim 43 \pm 8 \%$ of yellow mucus, compared to slugs exposed to PBS (negative control; pH 7.40) with a very low level of mucus production $(2 \pm 1 \%)$. These data are in good agreement with our previous reports. ${ }^{53,54}$ Mucus production recorded for the slugs exposed to the solutions of $\mathrm{PEOZ}, \mathrm{MA}_{10} \mathrm{PEOZ}, \mathrm{MA}_{25} \mathrm{PEOZ}$, and $\mathrm{MA}_{35} \mathrm{PEOZ}$ ( $\mathrm{pH} 7.47)$ was $2 \pm 1,3 \pm 1,3 \pm 1$, and $2 \pm 1 \%$ of colorless mucus, respectively. No significant differences $(p \gg 0.05)$ in mucus production were seen between values recorded for the negative control and test materials, indicating the nonirritating nature of both PEOZ and modified PEOZs (Figure S5 provides the images with $A$. lusitanicus slugs exposed to various test materials).

\section{CONCLUSIONS}

This study demonstrated successful methacrylation of poly(2ethyl-2-oxazoline) through a reaction between hydrolyzed poly(2-ethyl-2-oxazoline) bearing secondary amino groups and methacrylic anhydride. The structure and physicochemical behavior of these polymers were studied using ${ }^{1} \mathrm{H}$ NMR, FTIR, and UV/vis spectroscopies and differential scanning calorimetry. Methacrylated PEOZ showed temperature-dependent phase separation in aqueous solutions, and the cloud point temperature values were dependent on the degree of polymer modification. Cell toxicity studies demonstrated equivalent biocompatibility of the methacrylated polymers with the parent poly(2-ethyl-2-oxazoline), although the intermediate hydrolyzed product was toxic. Slug mucosal irritation tests demonstrated the nonirritant nature of methacrylated PEOZ. Methacrylation significantly increased mucoadhesion on the nasal mucosa tissue compared to parent poly(2-ethyl-2-oxazoline) attributed to the synergistic binding of methacrylate groups as well as residual secondary amines being available to interact with the mucosal surface. Methacrylated PEOZ can potentially be used as a mucoadhesive material in dosage forms for transmucosal drug delivery. 
To the best of our knowledge, this is the first study reporting the chemical modification of the PEOZ backbone to enhance the mucoadhesive properties of this emerging class of polymers.

\section{ASSOCIATED CONTENT}

\section{S1 Supporting Information}

The Supporting Information is available free of charge at https://pubs.acs.org/doi/10.1021/acsapm.1c01097.

(Figure S1) ${ }^{1} \mathrm{H}$ NMR spectra of PEOZ and hydrolyzed PEOZ in $\mathrm{D}_{2} \mathrm{O}$; (Figure S2) first-order kinetic plot for the hydrolysis of PEOZ $500 \mathrm{kDa}$ at $100{ }^{\circ} \mathrm{C},[\mathrm{HCl}]=18$ wt \%; (Table S1) composition of $\mathrm{P}$ (EOZ-co-EI) calculated from the standard curve in Figure S2; (Figure S3) ${ }^{1} \mathrm{H}$ NMR spectrum of $\mathrm{MA}_{55} \mathrm{PEOZ}$ in DMSO- $d_{6}$; (Figure S4) FTIR full spectra of PEOZ and MAPEOZ; (Table S2) retention values of $1 \mathrm{mg} / \mathrm{mL}$ glycol chitosan, PEOZ, $\mathrm{MA}_{10} \mathrm{PEOZ}, \mathrm{MA}_{25} \mathrm{PEOZ}$, and $\mathrm{MA}_{35} \mathrm{PEOZ}$ solutions using $0.05 \mathrm{mg} / \mathrm{mL}$ sodium fluorescein as the solvent and pure $0.05 \mathrm{mg} / \mathrm{mL}$ sodium fluorescein solution on sheep nasal mucosa as washed with different volumes of ANF ( $\mathrm{pH}=5.70)$; (Table S3) values of viability of HEK293 cells determined after treatment with different concentrations $(25,50,75,100,125$, and $150 \mu \mathrm{g} / \mathrm{mL})$ of PEOZ, $\mathrm{P}\left(\mathrm{EOZ}^{-c o-\mathrm{EI}_{15}}\right), \mathrm{P}(\mathrm{EOZ}-c o-$ $\left.\mathrm{EI}_{28}\right), \mathrm{P}\left(\mathrm{EOZ}-\mathrm{co}-\mathrm{EI}_{53}\right), \mathrm{MA}_{10} \mathrm{PEOZ}, \mathrm{MA}_{25} \mathrm{PEOZ}$, and $\mathrm{MA}_{35} \mathrm{PEOZ}$ for $72 \mathrm{~h}$; and (Figure S5) photographs of mucus production by Arion lusitanicus slugs in contact with positive ( $1 \%$ solution of $\mathrm{BAC}$ in $\mathrm{PBS}$ ) and negative (PBS solution) controls as well as PEOZ and its methacrylated derivatives $(1 \mathrm{mg} / \mathrm{mL}$ each $)$ after $60 \mathrm{~min}$ of exposure (PDF)

\section{AUTHOR INFORMATION}

\section{Corresponding Author}

Vitaliy V. Khutoryanskiy - Reading School of Pharmacy, University of Reading, Reading RG6 6DX, United Kingdom; ○ orcid.org/0000-0002-7221-2630; Phone: +44(0) 118 378 6119; Email: v.khutoryanskiy@reading.ac.uk

\section{Authors}

Xiaoning Shan - Reading School of Pharmacy, University of Reading, Reading RG6 6DX, United Kingdom

Sam Aspinall - Reading School of Pharmacy, University of Reading, Reading RG6 6DX, United Kingdom

Daulet B. Kaldybekov - Reading School of Pharmacy, University of Reading, Reading RG6 6DX, United Kingdom; Department of Chemistry and Chemical Technology, AlFarabi Kazakh National University, 050040 Almaty, Kazakhstan

Fhataheya Buang - Reading School of Pharmacy, University of Reading, Reading RG6 6DX, United Kingdom; Centre for Drug Delivery Research, Faculty of Pharmacy, Universiti Kebangsaan Malaysia, 50300 Kuala Lumpur, Malaysia

Adrian C. Williams - Reading School of Pharmacy, University of Reading, Reading RG6 6DX, United Kingdom

Complete contact information is available at: https://pubs.acs.org/10.1021/acsapm.1c01097

\section{Author Contributions}

The manuscript was written by X.S. and through contributions of all authors. All authors have given approval to the final version of the manuscript.

\section{Notes}

The authors declare no competing financial interest.

\section{ACKNOWLEDGMENTS}

The authors acknowledge the University of Reading and the China Scholarship Council (201707040071) for funding the Ph.D. studentship of X.S. The authors also thank the staff in the Chemical Analysis Facility (CAF, University of Reading) for assistance with thermal analysis. The authors thank Amnani Aminuddin for her technical help with cell culture experiments and the Faculty of Pharmacy UKM for providing the cell culture research facilities.

\section{ABBREVIATIONS}

PEOZ, poly(2-ethyl-2-oxazoline); P(EOZ-co-EI), poly[(2ethyl-2-oxazoline)-co-ethylenimine]; MAPEOZ, methacrylated PEOZ

\section{REFERENCES}

(1) Grassin-Delyle, S.; Buenestado, A.; Naline, E.; Faisy, C.; Blouquit-Laye, S.; Couderc, L. J.; Le Guen, M.; Fischler, M.; Devillier, P. Intranasal drug delivery: an efficient and non-invasive route for systemic administration: focus on opioids. Pharmacol. Ther. 2012, 134, 366-379.

(2) Türker, S.; Onur, E.; Özer, Y. Nasal route and drug delivery systems. Pharm. World Sci. 2004, 26, 137-142.

(3) Wattanakumtornkul, S.; Pinto, A. B.; Williams, D. B. Intranasal hormone replacement therapy. Menopause 2003, 10, 88-98.

(4) Fazil, M.; Hassan, M. Q.; Baboota, S.; Ali, J. Biodegradable intranasal nanoparticulate drug delivery system of risedronate sodium for osteoporosis. Drug Delivery 2016, 23, 2428-2438.

(5) Rapoport, A. M.; Bigal, M. E.; Tepper, S. J.; Sheftell, F. D. Intranasal Medications for the Treatment of Migraine and Cluster Headache. CNS Drugs 2004, 18, 671-685.

(6) Pires, A.; Fortuna, A.; Alves, G.; Falcão, A. Intranasal Drug Delivery: How, Why and What for? J. Pharm. Pharm. Sci. 2009, 12, 288-311.

(7) Bruinsmann, F. A.; Richter Vaz, G.; de Cristo Soares Alves, A.; Aguirre, T.; Raffin Pohlmann, A.; Staniscuaski Guterres, S.; Sonvico, F. Nasal Drug Delivery of Anticancer Drugs for the Treatment of Glioblastoma: Preclinical and Clinical Trials. Molecules 2019, 24, No. 4312

(8) Poovaiah, N.; Davoudi, Z.; Peng, H.; Schlichtmann, B.; Mallapragada, S.; Narasimhan, B.; Wang, Q. Treatment of neurodegenerative disorders through the blood-brain barrier using nanocarriers. Nanoscale 2018, 10, 16962-16983.

(9) Illum, L.; Jorgensen, H.; Bisgaard, H.; Krogsgaard, O.; Rossing, $\mathrm{N}$. Bioadhesive microspheres as a potential nasal drug delivery system. Int. J. Pharm. 1987, 39, 189-199.

(10) Pereswetoff-Morath, L. Microspheres as nasal drug delivery systems. Adv. Drug Delivery Rev. 1998, 29, 185-194.

(11) Björk, E.; Edman, P. Characterization of degradable starch microspheres as a nasal delivery system for drugs. Int. J. Pharm. 1990, 62, $187-192$.

(12) Muramatsu, K.; Maitani, Y.; Takayama, K.; Nagai, T. The Relationship Between the Rigidity of the Liposomal Membrane and the Absorption of Insulin After Nasal Administration of Liposomes Modified with an Enhancer Containing Insulin in Rabbits. Drug Dev. Ind. Pharm. 1999, 25, 1099-1105.

(13) Law, S. L.; Huang, K. J.; Chou, H. Y. Preparation of desmopressin-containing liposomes for intranasal delivery. J. Controlled Release 2001, 70, 375-382. 
(14) Iwanaga, K.; Matsumoto, S.; Morimoto, K.; Kakemi, M.; Yamashita, S.; Kimura, T. Usefulness of liposomes as an intranasal dosage formulation for topical drug application. Biol. Pharm. Bull. 2000, 23, 323-326.

(15) Witschi, C.; J. Mrsny, R. In Vitro Evaluation of Microparticles and Polymer Gels for Use as Nasal Platforms for Protein Delivery. Pharm. Res. 1999, 16, 382-390.

(16) Zhou, M.; D. Donovan, M. Intranasal mucociliary clearance of putative bioadhesive polymer gels. Int. J. Pharm. 1996, 135, 115-125.

(17) Sogias, I. A.; Williams, A. C.; Khutoryanskiy, V. V. Why is Chitosan Mucoadhesive? Biomacromolecules 2008, 9, 1837-1842.

(18) Tyagi, P.; Tyagi, S.; Kaufman, J.; Huang, L.; de Miguel, F. Local drug delivery to bladder using technology innovations. Urol. Clin. North Am. 2006, 33, 519-530.

(19) Ways, T. M. M.; Lau, W.; Khutoryanskiy, V. Chitosan and Its Derivatives for Application in Mucoadhesive Drug Delivery Systems. Polymers 2018, 10, No. 267.

(20) Davoudi, Z.; Peroutka-Bigus, N.; Bellaire, B.; Jergens, A.; Wannemuehler, M.; Wang, Q. Gut Organoid as a New Platform to Study Alginate and Chitosan Mediated PLGA Nanoparticles for Drug Delivery. Mar. Drugs 2021, 19, No. 282.

(21) Shi, L.; Zhang, J.; Zhao, M.; Tang, S.; Cheng, X.; Zhang, W.; Li, W.; Liu, X.; Peng, H.; Wang, Q. Effects of polyethylene glycol on the surface of nanoparticles for targeted drug delivery. Nanoscale 2021, 13, 10748-10764.

(22) Kolawole, O. M.; Lau, W. M.; Khutoryanskiy, V. V. Methacrylated chitosan as a polymer with enhanced mucoadhesive properties for transmucosal drug delivery. Int. J. Pharm. 2018, 550, $123-129$.

(23) Shitrit, Y.; Bianco-Peled, H. Acrylated chitosan for mucoadhesive drug delivery systems. Int. J. Pharm. 2017, 517, 247255.

(24) Davidovich-Pinhas, M.; Bianco-Peled, H. Alginate-PEGAc: a new mucoadhesive polymer. Acta Biomater. 2011, 7, 625-633.

(25) Porfiryeva, N. N.; Nasibullin, S. F.; Abdullina, S. G.; Tukhbatullina, I. K.; Moustafine, R. I.; Khutoryanskiy, V. V. Acrylated Eudragit E PO as a novel polymeric excipient with enhanced mucoadhesive properties for application in nasal drug delivery. Int. J. Pharm. 2019, 562, 241-248.

(26) Brannigan, R. P.; Khutoryanskiy, V. V. Synthesis and evaluation of mucoadhesive acryloyl-quaternized PDMAEMA nanogels for ocular drug delivery. Colloids Surf., B 2017, 155, 538-543.

(27) Tonglairoum, P.; Brannigan, R. P.; Opanasopit, P.; Khutoryanskiy, V. V. Maleimide-bearing nanogels as novel mucoadhesive materials for drug delivery. J. Mater. Chem. B 2016, 4, 65816587.

(28) Shtenberg, Y.; Goldfeder, M.; Schroeder, A.; Bianco-Peled, H. Alginate modified with maleimide-terminated PEG as drug carriers with enhanced mucoadhesion. Carbohydr. Polym. 2017, 175, 337346.

(29) Sahatsapan, N.; Rojanarata, T.; Ngawhirunpat, T.; Opanasopit, P.; Tonglairoum, P. 6-Maleimidohexanoic acid-grafted chitosan: A new generation mucoadhesive polymer. Carbohydr. Polym. 2018, 202, 258-264.

(30) Davidovich-Pinhas, M.; Bianco-Peled, H. Novel mucoadhesive system based on sulfhydryl-acrylate interactions. J. Mater. Sci.: Mater. Med. 2010, 21, 2027-2034.

(31) Kim, K.; Kim, K.; Ryu, J. H.; Lee, H. Chitosan-catechol: a polymer with long-lasting mucoadhesive properties. Biomaterials 2015, 52, 161-170.

(32) Khutoryanskiy, V. V. Advances in mucoadhesion and mucoadhesive polymers. Macromol. Biosci. 2011, 11, 748-764.

(33) Grabovac, V.; Guggi, D.; Bernkop-Schnurch, A. Comparison of the mucoadhesive properties of various polymers. Adv. Drug Delivery Rev. 2005, 57, 1713-1723.

(34) Bernkop-Schnurch, A. Thiomers: a new generation of mucoadhesive polymers. Adv. Drug Delivery Rev. 2005, 57, 15691582.
(35) Matsumoto, A.; Cabral, H.; Sato, N.; Kataoka, K.; Miyahara, Y. Assessment of Tumor Metastasis by the Direct Determination of CellMembrane Sialic Acid Expression. Angew. Chem., Int. Ed. 2010, 49, 5494-5497.

(36) Liu, A.; Peng, S.; Soo, J. C.; Kuang, M.; Chen, P.; Duan, H. Quantum dots with phenylboronic acid tags for specific labeling of sialic acids on living cells. Anal. Chem. 2011, 83, 1124-1130.

(37) Tong, T.; Qi, Y.; Bussiere, L. D.; Wannemuehler, M.; Miller, C. L.; Wang, Q.; Yu, C. Transport of artificial virus-like nanocarriers through intestinal monolayers via microfold cells. Nanoscale 2020, 12, 16339-16347.

(38) Kolawole, O. M.; Lau, W. M.; Khutoryanskiy, V. V. Synthesis and Evaluation of Boronated Chitosan as a Mucoadhesive Polymer for Intravesical Drug Delivery. J. Pharm. Sci. 2019, 108, 3046-3053.

(39) de la Rosa, V. R. Poly(2-oxazoline)s as materials for biomedical applications. J. Mater. Sci.: Mater. Med. 2014, 25, 1211-1225.

(40) Hoogenboom, R. Poly(2-oxazoline)s: a polymer class with numerous potential applications. Angew. Chem., Int. Ed. 2009, 48, $7978-7994$.

(41) Lorson, T.; Lubtow, M. M.; Wegener, E.; Haider, M. S.; Borova, S.; Nahm, D.; Jordan, R.; Sokolski-Papkov, M.; Kabanov, A. V.; Luxenhofer, R. Poly(2-oxazoline)s based biomaterials: A comprehensive and critical update. Biomaterials 2018, 178, 204-280.

(42) Chen, W.; Zhou, S.; Ge, L.; Wu, W.; Jiang, X. Translatable High Drug Loading Drug Delivery Systems Based on Biocompatible Polymer Nanocarriers. Biomacromolecules 2018, 19, 1732-1745.

(43) Glassner, M.; Vergaelen, M.; Hoogenboom, R. Poly(2oxazoline)s: A comprehensive overview of polymer structures and their physical properties. Polym. Int. 2018, 67, 32-45.

(44) Ways, T. M. M.; Lau, W. M.; Ng, K. W.; Khutoryanskiy, V. V. Synthesis of thiolated, PEGylated and POZylated silica nanoparticles and evaluation of their retention on rat intestinal mucosa in vitro. Eur. J. Pharm. Sci. 2018, 122, 230-238.

(45) Mansfield, E. D.; de la Rosa, V. R.; Kowalczyk, R. M.; Grillo, I.; Hoogenboom, R.; Sillence, K.; Hole, P.; Williams, A. C.; Khutoryanskiy, V. V. Side chain variations radically alter the diffusion of poly(2-alkyl-2-oxazoline) functionalised nanoparticles through a mucosal barrier. Biomater. Sci. 2016, 4, 1318-1327.

(46) Ruiz-Rubio, L.; Alonso, M. L.; Perez-Alvarez, L.; Alonso, R. M.; Vilas, J. L.; Khutoryanskiy, V. V. Formulation of Carbopol((R))/ Poly(2-ethyl-2-oxazoline)s Mucoadhesive Tablets for Buccal Delivery of Hydrocortisone. Polymers 2018, 10, No. 175.

(47) Abilova, G. K.; Kaldybekov, D. B.; Ozhmukhametova, E. K.; Saimova, A. Z.; Kazybayeva, D. S.; Irmukhametova, G. S.; Khutoryanskiy, V. V. Chitosan/poly(2-ethyl-2-oxazoline) films for ocular drug delivery: Formulation, miscibility, in vitro and in vivo studies. Eur. Polym. J. 2019, 116, 311-320.

(48) Abilova, G. K.; Kaldybekov, D. B.; Irmukhametova, G. S.; Kazybayeva, D. S.; Iskakbayeva, Z. A.; Kudaibergenov, S. E.; Khutoryanskiy, V. V. Chitosan/Poly(2-ethyl-2-oxazoline) Films with Ciprofloxacin for Application in Vaginal Drug Delivery. Materials 2020, 13, No. 1709.

(49) de la Rosa, V. R.; Bauwens, E.; Monnery, B. D.; De Geest, B. G.; Hoogenboom, R. Fast and accurate partial hydrolysis of poly(2ethyl-2-oxazoline) into tailored linear polyethylenimine copolymers. Polym. Chem. 2014, 5, 4957-4964.

(50) Sedlacek, O.; Janouskova, O.; Verbraeken, B.; Hoogenboom, R. Straightforward Route to Superhydrophilic Poly(2-oxazoline)s via Acylation of Well-Defined Polyethylenimine. Biomacromolecules 2019, 20, 222-230.

(51) Da Silva Barbi, M.; Carvalho, F. C.; Kiill, C. P.; Barud Hda, S.; Santagneli, S. H.; Ribeiro, S. J.; Gremiao, M. P. Preparation and Characterization of Chitosan Nanoparticles for Zidovudine Nasal Delivery. J. Nanosci. Nanotechnol. 2015, 15, 865-874.

(52) Khutoryanskaya, O. V.; Mayeva, Z. A.; Mun, G. A.; Khutoryanskiy, V. V. Designing Temperature-Responsive Biocompatible Copolymers and Hydrogels Based on 2-Hydroxyethyl(meth)acrylates. Biomacromolecules 2008, 9, 3353-3361. 
(53) Kaldybekov, D. B.; Filippov, S. K.; Radulescu, A.; Khutoryanskiy, V. V. Maleimide-functionalised PLGA-PEG nanoparticles as mucoadhesive carriers for intravesical drug delivery. Eur. J. Pharm. Biopharm. 2019, 143, 24-34.

(54) Khutoryanskaya, O. V.; Morrison, P. W.; Seilkhanov, S. K.; Mussin, M. N.; Ozhmukhametova, E. K.; Rakhypbekov, T. K.; Khutoryanskiy, V. V. Hydrogen-bonded complexes and blends of poly(acrylic acid) and methylcellulose: nanoparticles and mucoadhesive films for ocular delivery of riboflavin. Macromol. Biosci. 2014, 14, 225-234.

(55) Shan, X.; Williams, A. C.; Khutoryanskiy, V. V. Polymer structure and property effects on solid dispersions with haloperidol: Poly(N-vinyl pyrrolidone) and poly(2-oxazolines) studies. Int. J. Pharm. 2020, 590, No. 119884.

(56) Mees, M. A.; Hoogenboom, R. Full and partial hydrolysis of poly(2-oxazoline)s and the subsequent post-polymerization modification of the resulting polyethylenimine (co)polymers. Polym. Chem. 2018, 9, 4968-4978.

(57) Sedlacek, O.; Monnery, B. D.; Hoogenboom, R. Synthesis of defined high molar mass poly(2-methyl-2-oxazoline). Polym. Chem. 2019, 10, 1286-1290.

(58) Zhang, Q.; Weber, C.; Schubert, U. S.; Hoogenboom, R. Thermoresponsive polymers with lower critical solution temperature: from fundamental aspects and measuring techniques to recommended turbidimetry conditions. Mater. Horiz. 2017, 4, 109-116.

(59) Chen, F. P.; Ames, A. E.; Taylor, L. D. Aqueous solutions of poly(ethyloxazoline) and its lower consolute phase transition. Macromolecules 1990, 23, 4688-4695.

(60) Lin, P.; Clash, C.; Pearce, E. M.; Kwei, T. K.; et al. Solubility and miscibility of poly(ethyl oxazoline). J. Polym. Sci., Part B: Polym. Phys. 1988, 26, 603-619.

(61) Ouellette, R. J.; Rawn, J. D. Alkanes and Cycloalkanes. In Principles of Organic Chemistry; Academic Press, 2015; Chapter 3, pp 65-94.

(62) Lungu, C. N.; Diudea, M. V.; Putz, M. V.; Grudzinski, I. P. Linear and Branched PEIs (Polyethylenimines) and Their Property Space. Int. J. Mol. Sci. 2016, 17, No. 555.

(63) Hu, J.; Han, J.; Li, H.; Zhang, X.; Liu, Ll.; Chen, F.; Zeng, B. Human Embryonic Kidney 293 Cells: A Vehicle for Biopharmaceutical Manufacturing, Structural Biology, and Electrophysiology. Cells Tissues Organs 2018, 205, 1-8.

(64) Bauer, M.; Lautenschlaeger, C.; Kempe, K.; Tauhardt, L.; Schubert, U. S.; Fischer, D. Poly(2-ethyl-2-oxazoline) as alternative for the stealth polymer poly(ethylene glycol): comparison of in vitro cytotoxicity and hemocompatibility. Macromol. Biosci. 2012, 12, 986998.

(65) Wang, M.; Gustafsson, O. J. R.; Siddiqui, G.; Javed, I.; Kelly, H. G.; Blin, T.; Yin, H.; Kent, S. J.; Creek, D. J.; Kempe, K.; Ke, P. C.; Davis, T. P. Human plasma proteome association and cytotoxicity of nano-graphene oxide grafted with stealth polyethylene glycol and poly(2-ethyl-2-oxazoline). Nanoscale 2018, 10, 10863-10875.

(66) Yuan, W.; Li, H. Polymer-Based Nanocarriers for Therapeutic Nucleic Acids Delivery. In Nanostructures for Drug Delivery; Academic Press, 2017; Chapter 14, pp 445-460.

(67) Adriaens, E.; Remon, J. P. Gastropods as an evaluation tool for screening the irritating potency of absorption enhancers and drugs. Pharm. Res. 1999, 16, 1240-1244.

(68) Adriaens, E.; Dierckens, K.; Bauters, T. G. M.; Nelis, H. J.; Goethem, Fv.; Vanparys, P.; Remon, J. P. The mucosal toxicity of different benzalkonium chloride analogues evaluated with an alternative test using slugs. Pharm. Res. 2001, 18, 937-942.

(69) Callens, C.; Adriaens, E.; Dierckens, K.; Remon, J. P. Toxicological evaluation of a bioadhesive nasal powder containing a starch and carbopol $974 \mathrm{p}$ on rabbit nasal mucosa and slug mucosa. $J$. Controlled Release 2001, 76, 81-91.

(70) Ceulemans, J.; Vermeire, A.; Adriaens, E.; Remon, J. P.; Ludwig, A. Evaluation of a muco-adhesive tablet for ocular use. J. Controlled Release 2001, 77, 333-344.
(71) Dhondt, M. M.; Adriaens, E.; Roey, J. V.; Remon, J. P. The evaluation of the local tolerance of vaginal formulations containing dapivirine using the Slug Mucosal Irritation test and the rabbit vaginal irritation test. Eur. J. Pharm. Biopharm. 2005, 60, 419-425.

(72) Lenoir, J.; Adriaens, E.; Remon, J. P. New aspects of the Slug Mucosal Irritation assay: predicting nasal stinging, itching and burning sensations. J. Appl. Toxicol. 2011, 31, 640-648.

(73) Lenoir, J.; Bachert, C.; Remon, J. P.; Adriaens, E. The Slug Mucosal Irritation (SMI) assay: a tool for the evaluation of nasal discomfort. Toxicol. In Vitro 2013, 27, 1954-1961.

(74) Adriaens, E.; Remon, J. P. Evaluation of an alternative mucosal irritation test using slugs. Toxicol. Appl. Pharmacol. 2002, 182, 169175 . 